\title{
Opioidindusert kløe
}

\author{
Kløe er en hyppig forekommende bivirkning ved bruk av opioid- \\ analgetika, spesielt ved spinal og epidural administrasjon. Selv om \\ bivirkningen ikke er alvorlig, kan den være plagsom og påvirke pasien- \\ ters livskvalitet og vilje til å fortsette behandlingen. I denne artikkelen \\ beskriver vi forekomsten av opioidindusert kløe og hvilke mekanismer \\ som antas å ligge til grunn for bivirkningen. Vi presenterer også forslag \\ til hvordan fenomenet kan håndteres.
}

\author{
Joachim Frost \\ joachim.frost@legemidler.no \\ Olav Spigset \\ Avdeling for klinisk farmakologi \\ St. Olavs hospital \\ og \\ Institutt for laboratoriemedisin, \\ barne- og kvinnesykdommer \\ Norges teknisk-naturvitenskapelige universitet
}

Kløe kan ha mange årsaker. Både allergiske reaksjoner, hudlidelser og systemiske sykdomstilstander som kolestase, nyresvikt, tyreotoksikose, polycytemia vera og malignitet kan gi kløe som symptom. Videre er kløe en kjent bivirkning av en rekke legemidler, deriblant ACE-hemmere, NSAIDpreparater og flere typer antibiotika, samt opioider.

Opioider er en samlebetegnelse på forbindelser som kan bindes til og påvirke kroppens opioidreseptorer (1). Forbindelsene kan stamme helt eller delvis fra opiumsvalmuen eller være syntetiske substanser med tilsvarende virkning (1). Opioider har en sentral plass i behandling av moderate til sterke smerter. Tall fra Folkehelseinstituttet viser at det årlige forbruket av opioider $\mathrm{i}$ Norge har ligget stabilt i overkant av 36 millioner definerte døgndoser $i$ perioden 2007-11 (2), noe som tilsvarer rundt 100000 behandlingsdøgn med gjennomsnittsdoser av opioider hver dag.

Målet med denne artikkelen er å beskrive opioidindusert kløe som fenomen og å gi en praktisk veiledning i hvordan bivirkningen kan håndteres.

Grunnlaget for artikkelen er litteratursøk i PubMed og databasene UpToDate og Micromedex, samt forfatternes vurderinger basert på egne erfaringer fra klinisk praksis. Det er foretatt et skjønnsmessig utvalg av identifiserte artikler. Søk i PubMed ble foretatt med søkeordene «opiate», «opiates», «opioid», «opioids» og «opioid-induced» koblet sammen med søkeordene «pruritus» og «itch», samt ved bruk av Medical Subject Heading $(\mathrm{MeSH})$-termene «analgesics, opioid» og «pruritus».

\section{Forekomst}

Kløe forekommer hos anslagsvis $2-10 \%$ av alle som behandles med opioider (3). Ved intravenøs administrasjon er forekomsten $10-50 \%$ (4). Risikoen for opioidindusert kløe øker betydelig ved spinal og epidural administrasjon (3, 4). Bivirkningen ses da særlig hyppig hos fødende, hvor forekomsten er anslagsvis $\quad 60-100 \%$ sammenliknet med $30-60 \%$ hos ortopediske pasienter (3). Bakgrunnen for denne forskjellen er dårlig forstått, men en sammenheng med økte østrogennivåer under svangerskapet er foreslått (5).

\section{Mekanismer}

Patogenesen ved opioidindusert kløe er uavklart. Flere legemidler er kjent for å gi hudkløe via histaminfrigjøring fra mastceller $i$ huden. Dette er også demonstrert for opioidanalgetika. Det er foreslått at opioidrelatert histaminfrigjøring er mer uttalt for midler med lavere reseptoraffinitet, og at det opptrer hyppigst ved bruk av naturlige og semisyntetiske opioider $(6,7)$. Størst histaminfrigjøring er rapportert ved høye doser petidin og morfin, mens lave doser fentanyl og sufentanil gir minst histaminfrigjøring (6). Selv om opioider kan utløse histaminmedierte reaksjoner som urtikarielt utslett og kløe ved systemisk administrasjon, er det omdiskutert hvor stor rolle histaminfrigjøring spiller i utviklingen av opioidindusert kløe $(3,4)$. Hovedargumentet mot histamin som hovedmediator er at histaminfrigjøring ikke ser ut til å finne sted ved spinal og epidural administrasjon, og således ikke kan forklare den høye forekomsten av opioidindusert kløe her (4). Dokumentasjonsgrunnlaget for behandling med antihistaminer er begrenset $(4,8,9)$.

Både dyrestudier og kliniske forsøk taler for at $\mu$-opioid-reseptorsystemet er det vik- tigste setet for opioidindusert kløe, blant annet på bakgrunn av at $\mu$-reseptorantagonister kan reversere denne effekten (4). For den partielle $\mu$-reseptoragonisten buprenorfin er imidlertid hudkløe også oppgitt som vanlig/svært vanlig bivirkning i den norske preparatomtalen (10). Nyere studier har for $\varnothing v$ rig antydet at ubalanse i $\mu$ - og $\kappa$-opioidreseptorsystemene kan være del av patogenesen ved hudkløe generelt, underbygd av at $\kappa$-reseptoragonister er vist å ha kløehemmende effekt $(11,12)$.

Basert på kliniske behandlingsforsøk med dopamin $\mathrm{D}_{2}-$ og serotonin $5-\mathrm{HT}_{3}$-reseptorantagonister foreligger det noe dokumentasjon for at sentrale $\mathrm{D}_{2}-$ og 5- $\mathrm{HT}_{3}$-reseptorer kan være involvert i utviklingen av opioidindusert kløe $(3-5,13)$. Frigjøring av prostaglandiner er også blitt assosiert med opioidindusert kløe, men kliniske forsøk med ulike NSAID-preparater har vist motstridende resultater med tanke på behandlingseffekt (4). En metaanalyse av effekten av glukokortikoidet deksametason viste ingen signifikant effekt mot opioidindusert kløe ved spinal og epidural administrasjon av morfin (14).

\section{Praktisk håndtering}

Graden av plager vil variere fra pasient til pasient, og hos noen vil andre opioidrelaterte bivirkninger være mer brysomme. Som regel vil den klare sammenhengen i tid mellom debut av kløen og bruk av opioider være diagnostisk. Mulige behandlingsstrategier ved opioidindusert kløe er skissert i ramme 1.

Kliniske erfaringer fra legemiddelassistert behandling med peroralt administrert metadon eller buprenorfin hos rusmisbrukere tilsier at kløe som oftest er et oppstartsproblem. Bivirkningen kan imidlertid vedvare (15). $\AA$ avvente spontan remisjon eller

\section{Hovedbudskap}

- Kløe forekommer hos 2-10\% av alle som behandles med opioider

- Forekomsten er høyere ved intravenøs (10-50\%) og spinal/epidural administrasjon $(20-100 \%)$

- Det viktigste setet for opioidindusert kløe ser ut til å være $\mu$-opioid-reseptorsystemet

- Behandling med nalokson eller ondansetron har dokumentert effekt 


\section{Ramme 1}

\section{Mulige behandlingsstrategier ved opioidindusert kløe}

- Avvente spontan remisjon eller toleranseutvikling

- Dosereduksjon for å identifisere minste effektive analgetiske dose

- Bytte til et annet opioid med dokumentert effekt mot opioid-

toleranseutvikling vil derfor noen ganger være uakseptabelt for pasienten. Identifisering av minste effektive dose er generelt et godt prinsipp, og siden bivirkningen ser ut til å være doseavhengig (3), er dette anbefalt også i denne sammenheng.

Bytte til et annet opioid (opioidrotasjon) kan forsøkes, men kan i alminnelighet ikke forventes å oppheve opioidindusert kløe (8, 9). Heller ikke overgang til et opioid med antatt mindre histaminfrigjøring (f.eks. fentanyl) ser ut til å gi pålitelig reduksjon av bivirkningen $(8,9)$.

Det foreligger ikke tilstrekkelig dokumentasjon for å anbefale medikamentell behandling som profylakse mot opioidindusert kløe på generelt grunnlag (4). Det vil likevel kunne forekomme situasjoner der kløen blir behandlingskrevende. Klinisk vurdering av pasientens behov i den enkelte situasjon blir da avgjørende. Et klinisk poeng er at legemidler som reduserer forekomsten av opioidindusert kløe også kan redusere forekomsten av andre opioidinduserte bivirkninger som kvalme og oppkast, og dermed samlet sett gi en betydelig reduksjon i pasientens besvær. De mest aktuelle medikamentelle behandlingsalternativene for opioidindusert kløe er fremstilt i tabell 1.

Flere studier har evaluert effekten av komplette og partielle $\mu$-reseptorantagonister (nalokson, naltrekson, metylnaltrekson, nalbufin m.fl.) mot opioidindusert kløe, og et flertall av studiene viser positiv effekt $(4,8$, 13, 15). En amerikansk kasuistikk beskriver
- Tilleggsbehandling med et legemiddel indusert kløe (tab 1)

et tilfelle av uttalt og intraktabel opioidindusert hudkløe ved systemisk morfinbehandling som ikke responderte på behandling med antihistaminer eller opioidrotasjon til fentanyl eller hydromorfon (9). Derimot avtok pasientens kløe etter overgang til peroral behandling med oksykodon sammen med en lav dose nalokson intravenøst. I en ukontrollert studie av seks pasienter med uttalt opioidindusert kløe som ikke responderte på behandling med det sederende antihistaminet difenhydramin, rapporterte samtlige seks pasienter signifikant lindring av hudkløen etter behandling med den partielle $\mu$-reseptorantagonisten og $\kappa$-reseptoragonisten butorfanol gitt som nesespray, uten signifikante forskjeller i sedasjon eller smerteskår (8). Tre av pasientene var behandlet med epiduralanestesi med fentanyl og bupivakain, de øvrige tre var behandlet med pasientstyrt intravenøs eller subkutan smertepumpe med morfin eller hydromorfon.

Alt $\mathrm{i}$ alt er nalokson best studert av de midlene som er registrert i Norge, men det må administreres parenteralt på grunn av førstepassasjemetabolisme i leveren. Behandling med $\mu$-reseptorantagonister kan imidlertid også redusere den analgetiske opioideffekten, med unntak av metylnaltrekson som hovedsakelig virker på perifere $\mu$-reseptorer, og således ikke har signifikant påvirkning på opioidmedierte analgetiske effekter i sentralnervesystemet $(10,15)$.

Dopamin $\mathrm{D}_{2}$-reseptorantagonister som droperidol har dokumentert positiv effekt som forebyggende behandling, men studiene er få $(3,4)$. Vi er ikke kjent med at det foreligger studier med $\mathrm{D}_{2}$-antagonister for peroral bruk, som for eksempel haloperidol.

Serotonin $\quad 5-\mathrm{HT}_{3}$-reseptorantagonisten ondansetron har dokumentert effekt ved etablert opioidindusert kløe, men data er motstridende for effekten ved forebyggende bruk (4).

Kliniske effektstudier av behandling med histamin $\mathrm{H}_{1}$-reseptorantagonister er få og inkonklusive, og begrenser seg til førstegenerasjons antihistaminer med sederende effekt (4).

\section{Konklusjon}

Selv om det foreligger en rekke kliniske studier av ulike behandlingsalternativer ved

Tabell 1 Medikamentelle behandlingsalternativer for opioidindusert kløe

\begin{tabular}{|c|c|c|}
\hline Virkningsmekanisme & $\begin{array}{l}\text { Best studerte } \\
\text { virkestoff } \\
\text { registrert i Norge }\end{array}$ & Dokumentasjon for effekt \\
\hline Opioid $\mu$-reseptorantagonisme & Nalokson ${ }^{1}$ & God dokumentasjon $1(4,8,13,15)$ \\
\hline Serotonin $5-\mathrm{HT}_{3}$-reseptorantagonisme & Ondansetron & Noe dokumentasjon (4) \\
\hline Dopamin $\mathrm{D}_{2}$-reseptorantagonisme & Droperidol & Mangelfull dokumentasjon ${ }^{2}(3,4)$ \\
\hline Histamin $\mathrm{H}_{1}$-reseptorantagonisme & Prometazin & Mangelfull dokumentasjon (4) \\
\hline \multicolumn{3}{|c|}{$\begin{array}{l}1 \text { Nalokson og de ikke-godkjente preparatene nalbufin og butorfanol har godt dokumentert effekt ved fore- } \\
\text { byggende behandling. Ved etablert opioidindusert kløe har nalbufin best dokumentasjon, mens den er mer } \\
\text { begrenset for nalokson og butorfanol }\end{array}$} \\
\hline \multicolumn{3}{|c|}{${ }^{2}$ Det foreligger noe dokumentasjon for effekt av $D_{2}$-reseptorantagonister ved forebyggende behandling } \\
\hline
\end{tabular}

opioidindusert kløe, mangler fortsatt fullgode, omforente behandlingsanbefalinger. De fleste kliniske forsøk er dessuten utført i anestesiologisk sammenheng med spinal eller epidural opioidadministrasjon og med utvidede muligheter for klinisk overvåking og behandling, og vil ikke nødvendigvis være relevante i andre kliniske situasjoner.

\section{Joachim Frost (f. 1977)}

er lege og sivilingeniør i organisk kjemi. Han er ph.d.-stipendiat i klinisk medisin.

Forfatter har fylt ut ICMJE-skjemaet og oppgir ingen interessekonflikter.

\section{Olav Spigset (f. 1963)}

er professor i klinisk farmakologi og overlege. Forfatter har fylt ut ICMJE-skjemaet og oppgir ingen interessekonflikter.

\section{Litteratur}

1. Heroin, morfin - fakta om opioider. Oslo: Nasjonalt folkehelseinstitutt, 2012. www.fhi.no/eway/ default aspx?pid $=233 \& \operatorname{trg}=$ Main Left $5648 \&$ MainArea $5661=5648 \cdot 0: 15,2917 \cdot 1 \cdot 0: 0: 0: 0 \&$ Main Lef t_5648 $=5544: 51039: 1: 5647: 30: 0: 0$ (3.7.2012).

2. Legemiddelforbruket i Norge 2007-2011. Oslo: Nasjonalt folkehelseinstitutt, 2012 www. legemiddelforbruk no (3.7.2012).

3. Reich A, Szepietowski JC. Opioid-induced pruritus: an update. Clin Exp Dermatol 2010; 35: 2-6.

4. Ganesh A, Maxwell LG. Pathophysiology and management of opioid-induced pruritus. Drugs 2007: 67: 2323-33.

5. Szarvas S, Harmon D, Murphy D. Neuraxial opioid induced pruritus: a review. J Clin Anesth 2003; 15 234-9.

6. Pain control in the critically ill adult patient. Walt ham: UpToDate Inc., 2011. www.uptodate.com (3.7.2012).

7. Opioid analgesics - cross allergenicity. Micromedex 2.0. Philadelphia: Thomson Reuters (Healthcare), 2009. www. thomsonhc.com (3.7.2012)

8. Dunteman E, Karanikolas M, Filos KS. Transnasa butorphanol for the treatment of opioid-induced pruritus unresponsive to antihistamines. J Pain Symptom Manage 1996; 12: 255-60.

9. Tarcatu D. Tamasdan C, Moryl N et al. Are we still scratching the surface? A case of intractable pruritus following systemic opioid analgesia. J Opioid Manag 2007; 3: 167-70.

10. Legemiddelsøk. Oslo: Statens legemiddelverk, 2012. www.legemiddelverket.no/custom/ Preparatsok/prepSearch_80333.aspx (3.7.2012).

11. Dawn AG, Yosipovitch G. Butorphanol for treatment of intractable pruritus. J Am Acad Dermatol 2006: 54: 527-31.

12. Phan NQ, Lotts T, Antal A et al. Systemic kappa opioid receptor agonists in the treatment of chronic pruritus: a literature review. Acta Derm Venereol 2012 doi: 10.2340/00015555-1353

13. Kjellberg F, Tramèr MR. Pharmacological control of opioid-induced pruritus: a quantitative systematic review of randomized trials. Eur J Anaesthesio 2001: 18: 346-57.

14. Allen TK Jones CA, Habib AS. Dexamethasone for the prophylaxis of postoperative nausea and vomiting associated with neuraxial morphine administration: a systematic review and meta-analysis. Anesth Analg 2012: 114:813-22.

15. Friedman JD, Dello Buono FA. Opioid antagonists in the treatment of opioid-induced constipation and pruritus. Ann Pharmacother 2001; 35: 85-91. 